\title{
PERAN KEPUASAN MEMEDIASI CUSTOMER RELATIONSHIP MANAGEMENT TERHADAP LOYALITAS NASABAH BANK MEGA CABANG SUNSET ROAD KUTA
}

\author{
Anak Agung Istri Mas Vedanthi Putri ${ }^{1}$ \\ Ni Made Purnami ${ }^{2}$ \\ ${ }^{1,2}$ Fakultas Ekonomi dan Bisnis Universitas Udayana, Bali, Indonesia \\ Email: vedanthiputri@yahoo.com
}

\begin{abstract}
ABSTRAK
Dunia perbankan berkembang pesat dalam persaingan, menyebabkan banyak strategi dilakukan perusahaan dalam mempertahankan nasabahnya termasuk membangun hubungan baik jangka panjang. Penelitian ini bertujuan menjelaskan peran kepuasan memediasi customer relationship management terhadap loyalitas nasabah. Penelitian dilakukan di cabang Bank Mega Sunset Road Kuta Badung melibatkan 110 orang responden melalui metode purposive sampling. Data penelitian dikumpulkan melalui penyebaran kuesioner. Teknik analisis data yang digunakan adalah teknik analisis jalur dan uji sobel. Hasil penelitian menunjukkan customer relationship management berpengaruh positif dan signifikan terhadap loyalitas. Customer relationship management berpengaruh positif dan signifikan terhadap kepuasan. Kepuasanberpengaruh positif dan signifikan terhadap loyalitas. Kepuasansignifikan memediasi secara parsial hubungan customer relationship management dengan loyalitas, hal tersebut menunjukan bahwa customer relationship management yang disertai oleh kepuasan akan mempengaruhi tinggi rendahnya loyalitas nasabah.Penelitian ini diharapkan memberikan kontribusi bagi pengembangan ilmu pemasaran dan bahan pertimbanganperusahaan atau pelaku bisnis.
\end{abstract}

Kata kunci: loyalitas, customer relationship management, kepuasan

\begin{abstract}
Banking world is growing in competition, many strategies carried out bycompany in maintaining customers to build long-term good relations. This study explain the role of satisfaction mediating customer relationship management towards loyalty. The research was conducted at Bank Mega branch of Sunset Road Kuta Badung involving 110 respondents use purposive sampling method. The research collected by questionnaires. The analysis technique are path analysis and sobel. The results shows customer relationship management has a positive and significant effect on loyalty. Customer relationship management has a positive and significant effect on satisfaction. Satisfaction has a positive and significant effect on loyalty. Satisfaction significantly mediates partially customer relationship management relationships with loyalty, it shows that customer relationship management accompanied by satisfaction will affect the high and low customer loyalty. This research expected to contribute the science of marketing and consideration of companies or business people.

Keywords : loyalty, customer relationship management, satisfaction
\end{abstract}




\section{PENDAHULUAN}

Perbankan di Indonesia sedang mengalami pertumbuhan, data Statistika Perbankan Indonesia (SPI) yang diterbitkan oleh Otoritas Jasa Keuangan menunjukan pada tahun 2015 pendapatan Bank Umum sebesar 104,628 miliar, 2016 sebesar 106,544 miliar dan tahun 2017 sebesar 131,156 miliar (ojk.go.id, 2018). Peningkatan pendapatan tersebut disebabkan oleh banyaknya pesaing antar jasa karena perusahaan tentunya ingin selalu unggul dalam persaingan. Dunia perbankan dalam melakukan persaingan tidak hanya menimbulkan dampak positif sebagai pemicu peningkatan pendapatan, namun persaingan juga menimbulkan dampak negatif. Jumlah kantor Bank Swasta dan Bank Nasional yang memiliki izin di Indonesia mulai berkurang ditunjukan dalam data Badan Pusat Statistik (BPS) mengenai Jumlah Pembangunan Bank tahun 2015 sebanyak 32.963 cabang kantor Bank, tahun 2016 sebanyak 32.730 dan pada tahun 2017 sebanyak 32.285 cabang kantor Bank, berkurangnya kantor bank dikarenakan pailit maupun merger antar perusahaan (bps.go.id, 2018).

Keberadaan nasabah yang loyal sangat dibutuhkan oleh perusahaan, loyalitas nasabah menjadi penting bagi perusahaan agar tetap bertahan hidup dalam persaingan yang ketat (Hastuti, 2014). Bank Mega merupakan bank swasta di bawah naungan CT Group yang merupakan pengambil alihan dari pemegang sebelumnya yaitu usaha keluarga PT. Bank Karman pada tahun 1996 dan berganti nama menjadi PT. Bank Mega yang sebelumnya adalah PT. Mega Bank. Pada krisis ekonomi di tahun 1997 Bank Mega merupakan salah satu Bank yang tidak terpengaruh dan tetap tumbuh bersama dengan Bank HSBC dan Deutche 
Bank tanpa bantuan pemerintah. Pada tahun 2011 Bank Mega dikenai sanksi Bank Indonesia dan Masuk Rating Watch Negative atas kelemahan dalam pengendalian internal. Sanksi tersebut menyebabkan bank dilarang membuka kantor cabang baru, memperpanjang atau membuka deposito on call dan menawarkan deposito negotiable dalam jangka waktu satu tahun yang mempengaruhi pertumbuhan bank (detikfinance.com, 2011). Bank Mega memiliki pelayanan khusus bagi nasabah yaitu Layanan Individu yang meliputi program Mega Transfer, Mega Inkaso, Mega Kliring, Mega Intercity Clearing dan Mega SBD sehingga dapat diperoleh kepuasan nasabah dan berhubungan positif dengan loyalitas nasabah bank akan tetapi secara keseluruhan nasabah masih memiliki beberapa keluhan, sehingga perlu penelitian lebih lanjut untuk mengetahui harapan nasabah sehingga perusahaan dapat mempertahankan loyalitas nasabahnya.

Menurut Sabir (2014) dan Ramli (2015) salah satu faktor memperoleh kepuasan adalah hasil realitas dari persepsi dan ekspektasi nasabah. Regan et al. dalam Anggabrata dan Rahanata (2015) menyatakan bahwa kepuasan pelanggan merupakan suatu tingkatan dimana kebutuhan, keinginan serta harapan pelanggan dapat terpenuhi yang akan mengakibatkan terjadinya pembelian ulang atau kesetian yang berlanjut. Penelitian yang dilakukan Kitapci et al. (2014) menyatakan CRM tidak mempengaruhi kepuasan. Iriandini (2015) dan Venerian (2014) menyatakan CRM tidak berpengaruh positif dan signifikan terhadap loyalitas pelanggan sedangkan penelitian Eka Putra et al. (2017) yang menyatakan faktor CRM terbukti berpengaruh secara signifikan terhadap kepuasan nasabah, dan juga berpengaruh secara signifikan terhadap loyalitas nasabah. Berdasarkan 
Anak Agung Istri Mas Vedanthi Putri, Peran Kepuasan memediasi...

research gap yang ada antara CRM dengan loyalitas dan hasil kajian empiris yang ada Zakaria et al. (2013); Rizan et al. (2014); Kurnia Sari (2016) maka diperlukan variabel pemediasi kepuasan.

Loyalitas nasabah dapat diperoleh dengan berbagai indikator, salah satunya adalah CRM. Kotler dan Amstrong (2018) menyatakan bahwa CRM mengacu pada memperoleh dan menggunakan data pelanggan dari semua sumber kelola untuk interaksi pelanggan, melibatkan pelanggan dalam program perusahaan, dan membangun hubungan pelanggan. Menurut Erick Mang'unyi (2017) pelanggan yang menyebarkan persepsi positif tentang penyedia layanan cenderung menghasilkanhubungan yang lebih panjang, kepercayaan, dan komitmen terhadap perusahaan dan kesetiaan akan terus berlanjut. CRM memiliki banyak manfaat mulai dari layanan pelanggan yang unggul, peningkatan profitabilitas, penjualan, pengurangan operasional biaya, basis pelanggan yang membesar dan pasar yang lebih luas (Jamali et al., 2013; Kihara, 2015). Penelitian Chen (2014) menganggap bahwa loyalitas pelanggan mengacu pada bagaimana pelanggan memiliki sikap yang menguntungkan terhadap target e-retailer yang ditunjukkan melalui niat pembelian ulang dan perilaku. Berdasarkan pemaparan tersebut maka diperoleh hipotesis.

\section{$\mathrm{H}_{1} \quad$ : CRM berpengaruh positif dan signifikan terhadap Loyalitas Nasabah}

Salah satu faktor dalam mempengaruhi kepuasan pelanggan adalah CRM, yaitu bagaimana cara perusahaan dalam membangun relasi yang menciptakan kepuasan. Kepuasan pelanggan adalah target yang berubah-ubah, sehingga perusahaan harus mampu memenuhi kebutuhan pelanggan agar para pelanggan 
menjadi tetap puas dan loyal (Tarigan et al., 2017). Menurut Chinomona (2013) kepercayaan dari hubungan pelanggan dan perusahaan memiliki pengaruh yang kuat terhadap kepuasan pelanggan.

Customer relationship management (CRM) adalah kombinasi dari orang, proses, dan teknologi yang berusaha memahami pelanggan perusahaan untuk pendekatan terintegrasi dalam mengelolahubungan (Vanitha, 2014). Febrianingtyas et al. (2014) menemukan bahwa CRM yang terdiri dari variabel keuntungan bersama, komitmen, kebenaran, komunikasi berpengaruh secara simultan terhadap kepuasan. Penelitian Ariyunita Supar (2017) menunjukan hasil CRM berpengaruh positif dan signifikan terhadap kepuasan pelanggan, kepuasan konsumen seiring dengan penerapan customer relationship management yang baik. Melalui penjelasan tersebut maka diperoleh hipotesis penelitian berikut.

\section{$\mathrm{H}_{2} \quad$ : CRM berpengaruh positif dan signifikan terhadap Kepuasan Nasabah}

Pelanggan yang memiliki kepuasan berkepanjangan akan menghasilkan loyalitas terhadap perusahaan. Kepuasan pelanggan terhadap pembelian tergantung pada bukti kinerja sebuah produk yang relatif serupa dengan harapan pembeli (Rosy, 2018). Pelanggan yang memiliki pengalaman pembelian sesuai harapan akan memiliki peningkatan kepuasan (Khedkar, 2015).

Kepuasan memiliki hubungan positif dengan loyalitas merek karena pelanggan yang merasa lebih puas maka memiliki loyalitas yang tinggi terhadap perusahaan (Irianto Marist et al., 2014). Perusahaan harus memiliki prioritas terhadap kepuasan pelanggan mereka karena kepuasan adalah prediktor terkuat kesetiaan pelanggan, hal ini dapat dicapai dengan mendengarkan persyaratan atau 
harapan mereka dan kemudian dengan menciptakan produk dan layanan yang memenuhi kebutuhan dan keinginan mereka (Keisidou et al., 2013). Menurut Khairil Aswan (2013) dalam membentuk loyalitas pelanggan maka yang dibutuhkan oleh perusahaan adalah menciptakan kepuasan pelanggan berkepanjangan. Berdasarkan pemaparan tersebut maka diperoleh hipotesis.

$\mathrm{H}_{3} \quad$ : Kepuasan berpengaruh positif dan signifikan terhadap Loyalitas Nasabah

Customer Relationship Management memiliki peranan dalam mempengaruhi kepuasan yang berujung loyalitas. CRM yang sukses diberikan oleh departemen perusahaan dan sumber daya eksternal perusahaan dapat membuat prosespenyediaan produk atau layanan yang disesuaikan dengan pelanggan menjadi tepat waktu (Aurela Ramaj, 2015).

Ketika pelanggan merasa puas terhadap pelayanan yang didapatkan saat proses transaksi dan juga puas terhadap barang atau jasa yang didapatkan, besar kemungkinan mereka akan kembali lagi dan melakukan pembelian-pembelian yang lain (Hartiwi, 2013). Majid (2013) menyatakan bahwa kepuasan nasabah memiliki pengaruh yang terhadap kepercayaan dan loyalitas nasabah. Menurut Permadi (2013); dan Silvia et al. (2015) kepuasan dapat menjadi variabel mediasi yang berpengaruh kuat dalam mempengaruhi loyalitas pelanggan. Berdasarkan pemaparan diatas maka dapat disusun hipotesis.

$\mathrm{H}_{4} \quad$ : Kepuasan secara signifikan berperan memediasi pengaruh CRM dan Loyalitas Nasabah 


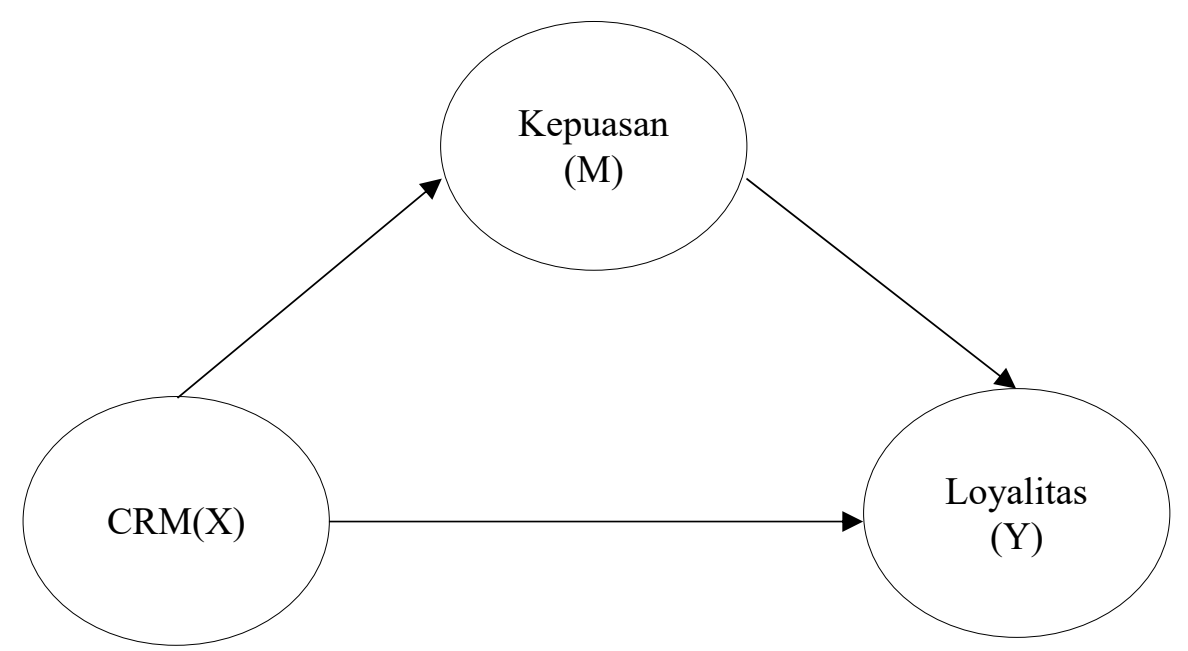

Gambar 1. Model Kerangka Konseptual

\section{METODE PENELITIAN}

Penelitian ini menggunakan metode asosiatif, membahas tentang pengaruh CRM terhadap loyalitas, pengaruh CRM terhadap kepuasan, pengaruh kepuasan terhadap loyalitas dan peran kepuasan dalam memediasi CRM terhadap loyalitas. Penelitian ini dilakukan di cabang Bank Mega Sunset Road, Kuta, Badung. Objek dalam penelitian ini adalah loyalitas yang dapat tumbuh ketika nasabah Bank Mega melakukan transaksi dan memiliki kepuasan terhadap CRM yang di berikan oleh perusahaan dengan identifikasi variabel bebas (X) adalah CRM, variabel terikat (Y) adalah loyalitas dan variabel mediasi (M) adalah kepuasan nasabah.

Data kuantitatif penelitian tabel 1. adalah usia responden, dan data jumlah nasabah berdasarkan gender dan data kualitatif pada penelitian ini adalah pendapat responden terhadap pernyataan yang meliputi CRM, kepuasan dan loyalitas. Sumber data penelitian ini meliputi:sumber primer yaitu responden yang langsung memberikan tanggapan terhadap variabel - variabel penelitian dan 
sumber sekunder dalam penelitian ini adalah sumber, berita - berita online, dan studi - studi empiris yang berkaitan dengan variabel terkait dalam penelitian ini.

Tabel 1.

Indikator Penelitian

\begin{tabular}{|c|c|c|}
\hline Variabel & Indikator & Sumber \\
\hline Loyalitas (Y) & $\begin{array}{l}\text { 1) Merekomendasikan orang lain untuk } \\
\text { membeli atau mereferensikan kepada } \\
\text { orang lain (Word of mouth) } \\
\text { 2) Menolak menggunakan produk lain atau } \\
\text { menunjukkan kekebalan terhadap tarikan } \\
\text { dari pesaing perusahaan (Reject another) } \\
\text { 3) Melakukan pembelian berulang (Repeat } \\
\text { purchasing). }\end{array}$ & $\begin{array}{l}\text { Kotler dan Keller (2016) } \\
\text { dan } \\
\text { Yulianti (2015) }\end{array}$ \\
\hline CRM (X) & $\begin{array}{l}\text { 1) Trust } \\
\text { 2) Commitment } \\
\text { 3) Communication } \\
\text { 4) Conflict handling }\end{array}$ & Kotler dan Amstrong (2018) \\
\hline $\begin{array}{l}\text { Kepuasan } \\
\text { Nasabah (M) }\end{array}$ & $\begin{array}{l}\text { 1) Customer superior service } \\
\text { 2) Unconditional guarantees } \\
\text { 3) Penanganan keluhan yang efisien } \\
\text { 4) Peningkatan kinerja perusahaan }\end{array}$ & Freddy Rangkuti (2014) \\
\hline
\end{tabular}

Sumber : data diolah,

Populasi dalam penelitian ini adalah nasabah Bank Mega cabang Sunset Road, Kuta, Badung yang berjumlah 1.601 orang. Metode penentuan sampel yang digunakan dalam penelitian ini yaitu non probability sampling.

Penelitian ini menggunakan teknik analisis jalur untuk menguji besarnya kontribusi yang dinyatakan oleh koefisien jalur pada setiap diagram jalur dari hubungan kausal dan Uji Sobel untuk menguji signifikansi pengaruh tidak langsung variabel CRM (X) terhadap variabel loyalitas (Y) melalui variabel kepuasan (M).

\section{HASIL DAN PEMBAHASAN}

Distribusi responden pada penelitian ini dapat dilihat dari Tabel 2. 
Tabel 2.

Karakteristik demografi responden

\begin{tabular}{lllll}
\hline No & Variabel & Klasifikasi & Frekuensi & $\begin{array}{c}\text { Presentase } \\
\text { (persen) }\end{array}$ \\
\hline 1 & Usia & $17-25$ & 4 & 3,64 \\
& & $26-30$ & 17 & 15,46 \\
& & & 89 & 80,90 \\
2 & Jumlah & & $\mathbf{1 1 0}$ & $\mathbf{1 0 0}$ \\
& Jenis Kelamin & Laki-laki & 55 & 50 \\
& Jumlah & Perempuan & 55 & 50 \\
3 & Pekerjaan & Pelajar & $\mathbf{1 1 0}$ & $\mathbf{1 0 0}$ \\
& & Pegawai Swasta & 1 & 0,90 \\
& & PNS & 26 & 23,64 \\
& & Wiraswasta & 81 & 1,82 \\
4 & Jumlah & & $\mathbf{1 1 0}$ & 73,64 \\
& Pendapatan & & 6 & $\mathbf{1 0 0}$ \\
& & $5.000 .00000-9.999 .999$ & 19 & 5,5 \\
& & $10.000 .000-14.999 .999$ & 14 & 17,27 \\
& & $15.000 .000-19.999 .999$ & 17 & 12,72 \\
& & $20.000 .000-24.999 .999$ & 19 & 17,45 \\
& & & 35 & 31,27 \\
& Jumlah & & $\mathbf{1 1 0}$ & 100 \\
\hline
\end{tabular}

Sumber: Data diolah, 2018

Berdasarkan pada Tabel 2. diketahui bahwa secara umum nasabah Bank Mega merupakan nasabah dengan usia lebih dari 30 tahun. Hal ini memiliki arti bahwa usia 30 tahun pada umumnya sudah memiliki tanggung jawab dalam merencanakan masa depan keuangan yang baik. Nasabah Bank Mega seimbang laki-laki dan perempuan, hal ini memiliki arti bahwa laki-laki dan perempuan memiliki kesadaran tentang pentingnya mengelola keuangan. Sebagian besar nasabah Bank Mega merupakan wiraswasta, hal ini memiliki arti Bank Mega memiliki produk yang dapat membantu pengelolaan keuangan wiraswasta. Secara umum nasabah memiliki pendapatan lebih dari 25.000 .000 per bulan, hal ini memiliki arti nasabah yang memiliki pendapatan lebih dari 25.000 .000 perbulan mempercayakan Bank Mega untuk mengatur keuangannya dimana, mayoritas nasabah merupakan wiraswasta yang mendapatkan kemudahan transaksi dari produk Bank Mega untuk kepentingan bisnisnya. 
Tabel 3.

Hasil Uji Validitas

\begin{tabular}{llll}
\hline Variabel & Instrumen & Pearson Correlation & Keterangan \\
\hline Loyalitas (Y) & Y1 & 0,791 & Valid \\
& Y2 & 0,824 & Valid \\
CRM (X) & Y3 & 0,864 & Valid \\
& X1 & 0,795 & Valid \\
& X2 & 0,729 & Valid \\
& X3 & 0,761 & Valid \\
Kepuasan & X4 & 0,801 & Valid \\
(M) & M1 & 0,892 & Valid \\
& M2 & 0,858 & Valid \\
& M3 & 0,826 & Valid \\
\hline
\end{tabular}

Sumber: Data diolah, 2018

Berdasarkan Tabel 3. menunjukan bahwa seluruh indikator pernyataan dalam variabel loyalitas, kepuasan nasabah, dan CRM memliki pearson correlation yang lebih besar dari 0,30. Disimpulkan bahwa seluruh indikator dalam variabel penelitian ini adalah valid sehingga dapat digunakan sebagai instrumen dalam penelitian.

Tabel 4.

Hasil Uji Reabilitas

\begin{tabular}{lll}
\hline Variabel & Cronbach's Alpha & Keterangan \\
\hline Loyalitas & 0,763 & Reliabel \\
CRM & 0,773 & Reliabel \\
Kepuasan Nasabah & 0,871 & Reliabel \\
\hline Sumber: Data diolah, 2018 & &
\end{tabular}

Berdasarkan Tabel 4. menunjukan bahwa seluruh instrument penelitian yaitu variabel loyalitas, CRM dan kepuasan nasabah memiliki koefisien cronbach's alpha yang lebih besar dari angka 0,60. Maka dari itu dapat disimpulkan bahwa seluruh indikator variabel dalam penelitian ini reliabel, sehingga dapat digunakan sebagai instrumen penelitian.

Deskripsi variabel data penelitian menyajikan penilaian responden pada setiap pernyataan yang diajukan dalam kuesioner. Penilaian responden meliputi 
penilaian terhadap variabel loyalitas, CRM dan kepuasan nasabah diukur dengan menggunakan skala pengukuran 1 sampai 5 yang dikelompokan sebagai berikut.

$$
\begin{aligned}
& \text { 1,00-1,79 = Sangat Tidak Baik } \\
& \text { 1,80-2,59 }=\text { Tidak Baik } \\
& \text { 2,60-3,39 = Cukup Baik } \\
& \text { 3,40-4,19= Baik } \\
& \text { 4,20-5,00 = Sangat Baik }
\end{aligned}
$$

Tabel 5.

Deskripsi Responden terhadap Loyalitas Nasabah

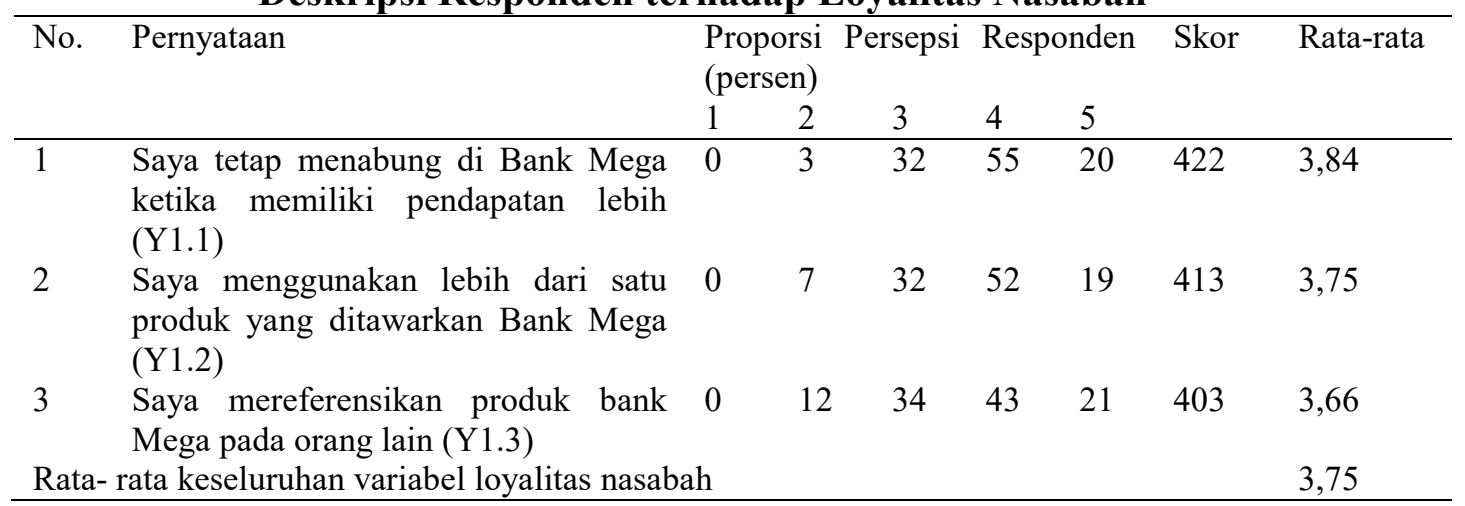

Secara keseluruhan nilai rata-rata total persepsi responden mengenai variabel loyalitas nasabah sebesar 3.75 dan termasuk pada kriteria baik. Hal ini mengindikasikan responden memiliki nilai yang baik pada perusahaan sehingga memiliki rasa loyalitas yang cukup baik.

Secara keseluruhan nilai rata-rata total persepsi responden mengenai CRM sebesar 3,82 dan masuk dalam kriteria baik yang berarti responden sudah merasakan adanya CRM dari perusahaan. Hal ini menjelaskan bahwa strategi untuk melayani konsumen dengan hubungan yang baik berjalan efektif. 
Tabel 6.

Deskripsi Persepsi Responden terhadap CRM

\begin{tabular}{|c|c|c|c|c|c|c|c|c|}
\hline \multirow[t]{2}{*}{ No. } & \multirow[t]{2}{*}{ Pernyataan } & \multicolumn{2}{|c|}{$\begin{array}{l}\text { Proporsi } \\
\text { (persen) }\end{array}$} & \multirow{2}{*}{$\begin{array}{l}\text { Persepsi } \\
3 \\
\end{array}$} & \multicolumn{2}{|c|}{ Responden } & \multirow[t]{2}{*}{ Skor } & \multirow[t]{2}{*}{ Rata-rata } \\
\hline & & 1 & 2 & & 4 & 5 & & \\
\hline 1 & $\begin{array}{l}\text { Saya memiliki rasa percaya pada } \\
\text { perusahaan dalam memenuhi } \\
\text { keutuhan saya (X1.1) }\end{array}$ & 0 & 2 & 30 & 63 & 15 & 421 & 3,83 \\
\hline 2 & $\begin{array}{l}\text { Perusahaan memiliki komitmen } \\
\text { memberikan pelayanan yang baik } \\
\text { pada saya }(\mathrm{X} 1.2)\end{array}$ & 0 & 3 & 38 & 56 & 13 & 409 & 3,72 \\
\hline 3 & $\begin{array}{l}\text { Perusahaan melakukan komunikasi } \\
\text { yang baik pada saya (X1.3) }\end{array}$ & & 4 & 30 & 46 & 30 & 432 & 3,93 \\
\hline 4 & $\begin{array}{l}\text { Perusahaan dapat mengelola keluhan } \\
\text { saya (X1.4) }\end{array}$ & 0 & 4 & 34 & 50 & 22 & 420 & 3,82 \\
\hline \multicolumn{2}{|c|}{ Rata- rata keseluruhan variabel CRM } & & & & & & & 3,82 \\
\hline
\end{tabular}

Sumber: Data diolah, 2018

Tabel 7.

Deskripsi Persepsi Responden terhadap Kepuasan Nasabah

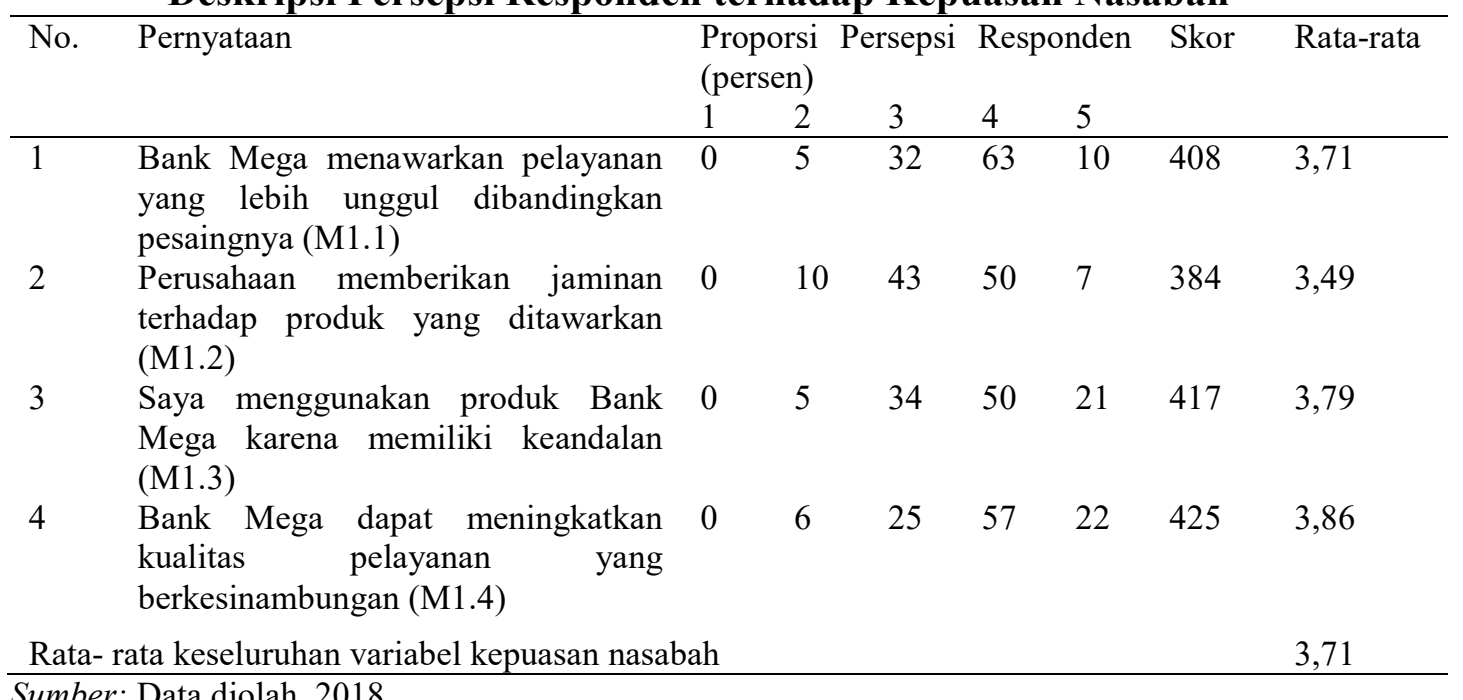

Secara keseluruhan nilai rata-rata total persepsi responden mengenai variabel kepuasan nasabah sebesar 3,71 dan angka tersebut masuk dalam kriteria baik yang berarti responden sudah memiliki kepuasan yang diperoleh dari pelayanan perusahaan. Hal ini menunjukan bahwa perusahaan dapat meraih kepuasan nasabah secara baik. 
Uji Analisis Jalur dilakukan untuk menguji hubungan kausalitas antara dua atau lebih variabel.

Tabel 8.

Hasil Analisis Jalur Persamaan Regresi 1

\begin{tabular}{|c|c|c|c|c|c|}
\hline Variabel & B & Std. Error & Beta & $\mathrm{T}$ & Sig. \\
\hline $\begin{array}{c}\text { (Constant) } \\
\text { CRM }\end{array}$ & $\begin{array}{l}0,918 \\
0,731\end{array}$ & $\begin{array}{l}0,275 \\
0,071\end{array}$ & 0,703 & $\begin{array}{c}3,341 \\
10,272\end{array}$ & $\begin{array}{l}0,001 \\
0,000\end{array}$ \\
\hline
\end{tabular}

$\mathrm{R}_{1}^{2}: 0,494 \quad$ F Statistik : $105,512 \quad$ Sig F : 0,000

Sumber: Data diolah, 2018

Persamaan struktural dari hasil analisis jalur subtruktur 1 yang disajikan pada Tabel 8 .

$$
\begin{aligned}
& M=\beta_{2} X_{1}+\varepsilon_{1} \\
& M=0,703 X
\end{aligned}
$$

Nilai $\beta_{2}$ adalah sebesar 0,703 mengindikasi bahwa CRM berpengaruh positif terhadap kepuasan nasabah, semakin tinggi CRM maka kepuasan nasabah meningkat. Pengolahan data persamaan regresi 2 disajikan dalam Tabel 9 berikut.

Tabel 9.

\begin{tabular}{|c|c|c|c|c|c|}
\hline Variabel & $\mathrm{B}$ & Std. Error & Beta & $\mathrm{T}$ & Sig. \\
\hline $\begin{array}{ll}1 & \text { (Constant) }\end{array}$ &,- 042 & 0,288 & &,- 147 & 0,883 \\
\hline CRM & 0,690 & 0,100 & 0,576 & 6,913 & 0,000 \\
\hline Kepuasan & 0,311 & 0,096 & 0,270 & 3,243 & 0,002 \\
\hline $\mathrm{R}_{2}^{2}: 0,624$ & F Statistik : 88,791 & Sig. F : 0,000 & & & \\
\hline
\end{tabular}

Hasil Analisis Jalur Persamaan Regresi 2

Persamaan struktural dari hasil analisis jalur subtruktur 2 yang disajikan pada Tabel 9 adalah sebagai berikut.

$$
\begin{aligned}
& \mathrm{Y}=\beta_{1} \mathrm{X}_{1}+\beta_{3} \mathrm{M}_{1}+\varepsilon_{2} . . \\
& \mathrm{Y}=0,576 \mathrm{X}+0,270 \mathrm{M}
\end{aligned}
$$

Nilai $\beta_{1}$ adalah sebesar 0,576 memiliki arti bahwa CRM berpengaruh positif terhadap loyalitas, jika CRM meningkat maka loyalitas nasabah meningkat. Nilai $\beta_{3}$ adalah 0,270 memiliki arti bahwa kepuasan berpengaruh positif terhadap 
loyalitas nasabah, sehingga jika kepuasan meningkat maka loyalitas nasabah meningkat. Langkah selanjutnya adalah Membentuk koefisien jalur sebagai berikut : Pengaruh variabel CRM (X) terhadap variabel loyalitas (Y) adalah sebesar $\beta_{1}=0,576$, pengaruh variabel CRM (X) terhadap variabel kepuasan (M) adalah sebesar $\beta_{2}=0,703$, pengaruh variabel kepuasan nasabah $(\mathrm{M})$ terhadap variabel loyalitas $(\mathrm{Y})$ adalah sebesar $\beta_{3}=0,270$, pengaruh variabel CRM (X) terhadap variabel loyalitas nasabah (Y) dengan variabel kepuasan nasabah (M) sebagai variabel mediasi, sebagai berikut.

Pengaruh tidak langsung $=\beta_{2} \times \beta_{3}$

$$
=0,703 \times 0,270=0,189
$$

Pengaruh tidak langsung sebesar 0,189 menunjukan bahwa kepuasan nasabah berpengaruh secara tidak langsung sebesar 18,9 persen terhadap hubungan CRM dan loyalitas.

Total pengaruh variabel CRM (X) terhadap variabel loyalitas asabah (Y) melalui variabel kepuasan nasabah $(\mathrm{M})$, sebagai berikut.

$$
\begin{aligned}
\text { Pengaruh total } & =\beta_{1}+\left(\beta_{2} \times \beta_{3}\right) \ldots \ldots \ldots \ldots \ldots \ldots \ldots \ldots \ldots \\
& =0,576+(0,703 \times 0,270)=0,765
\end{aligned}
$$

Pengaruh total sebesar 0,765 memiliki arti bahwa secara total CRM mampu mempengaruhi loyalitas yang dimediasi oleh kepuasan nasabah sebesar 76,5 persen.

Setelah membentuk koefisien jalur selanjutnya adalah menguji nilai koefisien determinasi $\left(\mathrm{R}^{2}\right)$ dan standard Error (E).Menguji nilai koefisien determinasi $\left(\mathrm{R}^{2}\right)$ dan standard error $(\mathrm{E})$ dapat dilakukan setelah perhitungan hasil analisis jalur substruktrual 1 dan substruktur 2 dan dapat disusun model diagram 
jalur akhir. Nilai standard error yang dihitung sebelum menyusun model diagram jalur akhir adalah sebagai berikut.

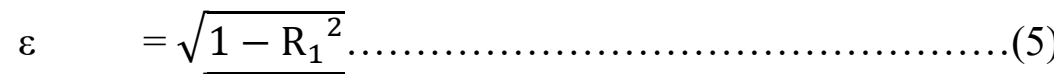

$$
\begin{aligned}
& \varepsilon_{1} \quad=\sqrt{1-\mathrm{R}_{1}{ }^{2}} \\
& =\sqrt{1-0,494}=0,506 \\
& \varepsilon_{2}=\sqrt{1-\mathrm{R}_{2}{ }^{2}} \\
& =\sqrt{1-0,624}=0,376
\end{aligned}
$$

Berdasarkan hasil standard error ( $(\varepsilon)$ yang telah dihitung, maka diketahui pengaruh error $_{1}\left(\varepsilon_{1}\right)$ sebesar 0,506 dan pengaruh error $2\left(\varepsilon_{2}\right)$ sebesar 0,376 sehingga diperoleh perhitungan nilai koefisien determinasi total yaitu sebagai berikut.

$$
\begin{aligned}
\mathrm{R}^{2} \mathrm{~m} & =1-\left(\mathrm{P} \varepsilon_{1}\right)_{1}{ }^{2}\left(\mathrm{P} \varepsilon_{2}\right)_{2}{ }^{2} \ldots \\
& =1-(0,506)^{2}(0,376)^{2} \\
& =1-(0,253)(0,188) \\
& =1-0,475 \quad=0,952
\end{aligned}
$$

Berdasarkan hasil perhitungan nilai koefisien determinasi total sebesar 0,952 mengindikasikan bahwa sebesar 95,2 persen variasi loyalitas nasabah dipengaruhi oleh variasi Kepuasan dan CRM, sedangkan sisanya sebesar 4,8 persen dijelaskan oleh faktor lain yang tidak dimasukan ke dalam model.

Hasil pengujian pada Tabel 9 diperoleh nilai koefisien $\mathrm{F} \leq 0,05$ dengan koefisien yang signifikan yaitu $0,000 \leq 0,05$, sehingga dapat disimpulkan bahwa $\mathrm{H}_{0}$ ditolak dan $\mathrm{H}_{1}$ diterima. Berdasarkan hasil tersebut dapat diketahui bahwa CRM dan kepuasan nasabah dapat berpengaruh secara simultan dan signifikan terhadap loyalitas nasabah dan model struktural ini telah memenuhi syarat goodness of fit melalui uji F. Setelah itu langkah selanjutya adalah menghitung koefisien jalur secara parsial hubungan CRM (X) dengan loyalitas nasabah (Y). 
Anak Agung Istri Mas Vedanthi Putri, Peran Kepuasan memediasi...

$\mathrm{H}_{0}$ : Tidak terdapat hubungan yang positif dan signifikan antara CRM dengan loyalitas.

$\mathrm{H}_{1}$ :Terdapat hubungan yang positif dan signifikan antara CRM dengan loyalitas.

Hasil analisis pengaruh CRM terhadap Loyalitas pada Tabel 9 diketahui memiliki nilai koefisien beta sebesar 0,576 dengan nilai signifikan t $0,000<0,05$, sehingga $\mathrm{H}_{0}$ ditolak dan $\mathrm{H}_{1}$ diterima. Hasil tersebut mengindikasikan bahwa terdapat hubungan yang positif dan signifikan antara CRM dengan loyalitas nasabah. Hubungan CRM (X) dengan Kepuasan nasabah (M).

$\mathrm{H}_{0}$ : Tidak terdapat hubungan yang positif dan signifikan antara CRM dengan kepuasan.

$\mathrm{H}_{1}$ :Terdapat hubungan yang positif dan signifikan antara CRM dengan kepuasan.

Hasil analisis pengaruh CRM terhadap kepuasan pada Tabel 8 diketahui memiliki nilai koefisien beta sebesar 0,703 dengan nilai signifikan t $0,000<0,05$, sehingga $\mathrm{H}_{0}$ ditolak dan $\mathrm{H}_{1}$ diterima. Hasil tersebut mengindikasikan bahwa terdapat hubungan yang positif dan signifikan antara CRM dengan kepuasan nasabah. Hubungan kepuasan nasabah (M) dengan loyalitas nasabah (Y).

$\mathrm{H}_{0}$ : Tidak terdapat hubungan yang positif dan signifikan antara kepuasan dengan loyalitas.

$\mathrm{H}_{1}$ :Terdapat hubungan yang positif dan signifikan antara kepuasan dengan loyalitas. 
Hasil analisis pengaruh CRM terhadap loyalitas pada Tabel 9 diketahui memiliki nilai koefisien beta sebesar 0,270 dengan nilai signifikan t $0,000<0,05$, sehingga $\mathrm{H}_{0}$ ditolak dan $\mathrm{H}_{1}$ diterima. Hasil tersebut mengindikasikan bahwa terdapat hubungan yang positif dan signifikan antara kepuasan nasabah dengan loyalitas nasabah.Hasil hipotesis penelitian analisis koefisien jalur yang telah dihitung sebelumnyaakan digambarkan pada Gambar 2. Perhitungan pengaruh antar variabel tersebut akan dirangkum dalam Tabel 10.

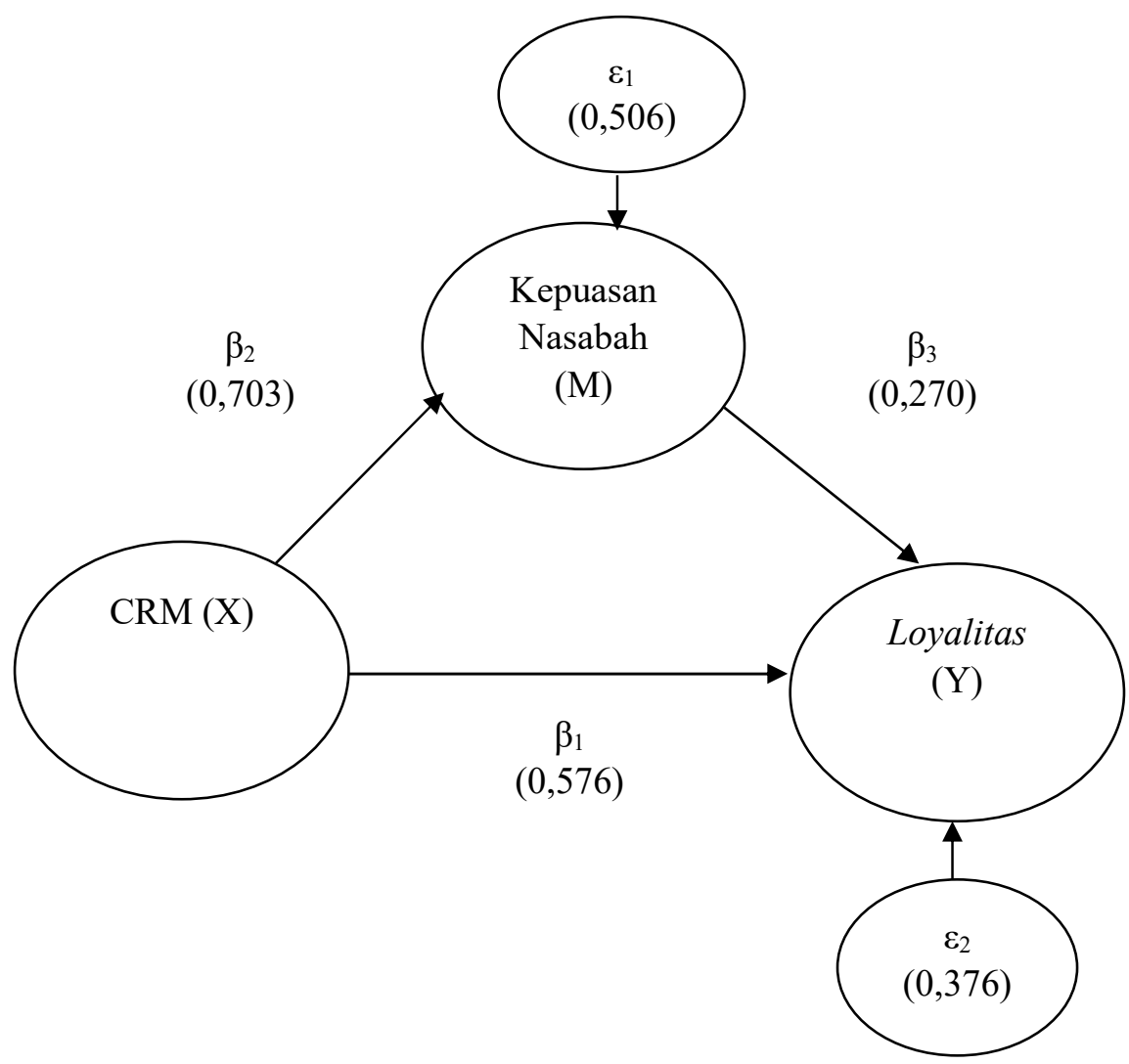

\section{Gambar 2. Validasi Model Jalur Akhir.}

Berdasarkan Tabel 10. dapat diketahui bahwa pengaruh langsung variabel CRM terhadap loyalitas nasabah memiliki nilai koefisien beta sebesar 0,576 , sedangkan pengaruh tidak langsung yang dimediasi oleh kepuasan nasabah menunjukan nilai koefisien beta sebesar 0,189. Hasil tersebut mengindikasikan 
bahwa kepuasan nasabah memediasi hubungan CRM terhadap loyalitas dengan pengaruh total yang diperoleh sebesar 0,756 .

Tabel 10.

Pengaruh Langsung, Tak Langsung dan Pengaruh Total Variabel CRM (X), Kepuasan (M), Loyalitas (Y)

\begin{tabular}{llll}
\hline $\begin{array}{l}\text { Pengaruh } \\
\text { Variabel }\end{array}$ & Pengaruh Langsung & $\begin{array}{l}\text { Pengaruh Tidak langsung Melalui } \\
\text { Kepuasan } \\
(\mathrm{M})=\left(\beta_{2} \times \beta_{3}\right)\end{array}$ & Pengaruh Total \\
\hline $\mathrm{X} \rightarrow \mathrm{M}$ & 0,703 & - & 0,703 \\
$\mathrm{X} \rightarrow \mathrm{Y}$ & 0,576 & $0,703 \times 0,270=0,189$ & 0,756 \\
$\mathrm{M} \rightarrow \mathrm{Y}$ & 0,270 & - & 0,270 \\
\hline \multicolumn{2}{l}{ Sumber: } &
\end{tabular}

Uji asumsi klasik dilakukan bertujuan untuk memastikan hasil yang diperoleh dapat memenuhi asumsi dasar dalam melakukan analisis regresi. Hasil uji asumsi klasik dalam penelitian ini dilakukan dengan uji normalitas, uji multikolinearitas dan uji heteroskedastisitas disajikan sebagai berikut.

Pengujian data dalam penelitian ini menggunakan uji Kolmogorov-smirnov dengan hasil Asymp, Sig (2-tailed) yang lebih besar dari 0,05. Nilai Asymp, Sig (2tailed) lebih besar daripada 0,05 maka data tersebut dapat dikatakan berdistribusi normal.

Uji Model regresi yang baik seharusnya tidak mengalami gejala multikolinier, nilai cut off yang secara umum dipakai untuk menunjukan adanya nilai multikolinearitas adalah nilai tolerance dibawah 0,10 atau sama dengan niai VIF dibawah 10. Hasil uji multikolinearitas dapat dilihat pada Tabel 4.10 berikut.

Tabel 11. Hasil Uji Multikolinearitas Persamaan Regresi 2

\begin{tabular}{lll}
\hline Variabel & Tolerance & VIF \\
\hline CRM & 0,506 & 1,977 \\
Kepuasan & 0,506 & 1,977 \\
\hline
\end{tabular}


Berdasarkan Tabel 11. dapat dilihat bahwa koefisien tolerance 0,506 yang berarti koefisien tolerance lebih besar dari 0,10 dan nilai VIF masing-masing 1,977 lebih kecil dari 10. Hal ini menunjukan bahwa tidak terdapat gejala multikolinearitas dan juga tidak adanya korelasi antara variabel bebas yang digunakan, sehingga model regresi penelitian ini layak digunakan untuk memprediksi.

Model regresi yang baik adalah yang tidak megandung gejala heteroskedastisitas atau mempunyai varian yang homogen. Jika signifikansi diatas ataupun mendekati 0,05 pada uji glejser maka model dapat dikatakan bebas dari gejala heteroskedastisitas. Hasil uji heteroskedastisitas dapat dilihat pada Table 12 dan 13 berikut.

Tabel 12.

Hasil Uji Heteroskedastisitas Persamaan Regresi 1

\begin{tabular}{ll}
\hline Variabel & Sig. \\
\hline CRM & 0,431 \\
\hline Sumber: Data diolah, 2018 &
\end{tabular}

Tabel 13.

Hasil Uji Heteroskedastisitas Persamaan Regresi 2

\begin{tabular}{ll}
\hline Variabel & Sig. \\
\hline CRM & 0,673 \\
Kepuasan & 0,319 \\
\hline Suber: Data diogh, 2018
\end{tabular}

Sumber: Data diolah, 2018

Berdasarkan Tabel 12. dapat diketahui bahwa nilai signfikansi dari variabel CRM sebesar 0,431 dan pada Tabel 13. dapat dilihat bahwa signifikasi dari variabel CRM sebesar 0,673 serta variabel kepuasan sebesar 0,319 sehingga nilai tersebut lebih besar dari 0,05 . Hal ini mengindikasikan bahwa tidak ada pengaruh antara variabel bebas terhadap absolute residual sehingga model regresi bebas dari gejala heteroskedastisitas. 
Uji sobel dilakukan bertujuan untuk mengetahui signifikansi dari hubungan tidak langsung antara variabel independen dengan variabel dependen yang dimediasi oleh variabel mediator. Variabel terbukti sebagai pemediasi jika memiliki kriteria (1) adanya pengaruh dari CRM terhadap loyalitas,berdasarkan Lampiran 10 didapatkan nilai direct effect sebesar 0,766 dengan koefisien signifikansi $0,000<0,05$ yang mengindikasikan ada pengaruh yang signifikan dari CRM ke loyalitas. (2) ada pengaruh yang signifikan dari CRM terhadap kepuasan dan pengaruh yang signifikan dari kepuasan terhadap loyalitas, berdasarkan laporan regresi pada Tabel 8 dan Tabel 9 terbukti adanya pengaruh signifikan dari CRM ke kepuasan dengan koefisien jalur sebesar 0,703 dan signifikansi 0,000 demikian juga adanya pengaruh signifikan antara kepuasan terhadap loyalitas dengan koefisien jalur sebesar 0,270 dan signifikansi sebesar 0,002 .

Uji sobel dihitung dengan menggunakan aplikasi Microsoft Excel. Apabila nilai Z lebih besar dari 1,96 (dengan tingkat kepercayaan sebesar 95 persen), maka dapat dinyatakan bahwa variabel mediator dinilai secara signifikan memediasi hubungan antara variabel bebas dan variabel terikat. Perhitungan uji sobel dapat dilihat sebagai berikut.

$$
\mathrm{z} \quad=\frac{\mathrm{ab}}{\sqrt{\mathrm{b}^{2} \mathrm{Sa}^{2}+\mathrm{a}^{2} \mathrm{Sb}^{2}+\mathrm{Sa}^{2} \mathrm{Sb}^{2}}} .
$$

Keterangan:

$$
\begin{aligned}
\mathrm{a} & =0,703 \\
\mathrm{~S}_{\mathrm{a}} & =0,071 \\
\mathrm{~b} & =0,27 \\
\mathrm{~S}_{\mathrm{b}} & =0,096 \\
\mathrm{z} & =\frac{\mathrm{ab}}{\sqrt{\mathrm{b}^{2} \mathrm{Sa}^{2}+\mathrm{a}^{2} \mathrm{Sb}^{2}+\mathrm{Sa}^{2} \mathrm{Sb}^{2}}} \\
\mathrm{z} & =\frac{(0,703)(0,0,27)}{\sqrt{(0,27)^{2}(0,071)^{2}+(0,703)^{2}(0,096)^{2}+(0,071)^{2}(0,096)^{2}}}
\end{aligned}
$$




$$
\mathrm{Z} \quad=2,70
$$

Berdasarkan pada hasil uji diketahui bahwa nilai $\mathrm{Z}$ sebesar 2,70 yang menunjukan bahwa nilai ini lebih besar dari 1,96 dengan tingkat signifikansi 0,000. Hal ini mengindikasikan bahwa variabel kepuasan dinilai mampu memediasi secara parsial hubungan antara CRM dengan loyalitas nasabah.

Pengujian hipotesis yang dilakukan pada pengaruh CRM terhadap loyalitas nasabah dengan tingkat signifikansi pada probabilitas (p) sebesar 0,000 (kurang dari 0,05$)$ serta koefisien beta standardized sebesar 0,576 yang berarti bahwa hasil penelitian ini mendukung $\mathrm{H}_{1}$. Hasil tersebut mengindikasikan bahwa CRM berpengaruh positif dan signifikan terhadap loyalitas nasabah. Hal ini menunjukan bahwa semakin baik perusahaan menerapkan CRM dalam membangun suatu hubungan maka semakin tinggi loyalitas nasabah pada perusahaan.

Pengaruh hubungan antara variabel CRM terhadap kepuasan nasabah dan memperoleh koefisien tingkat signifikansi pada probabilitas $(\mathrm{p})$ sebesar 0,000 (kurang dari 0,05) serta koefisien beta standardized sebesar 0,073 yang berarti bahwa hasil penelitian ini mendukung $\mathrm{H}_{2}$. Hasil tersebut menunjukan bahwa CRM berpengaruh positif dan signifikan terhadap kepuasan nasabah. Berdasarkan hasil tersebut dapat diketahui bahwa semakin baik perusahaan meningkatkan kinerja pada menerapkan CRM dalam memberikan pelayanan pada nasabah maka semakin tinggi kepuasan yang diperoleh nasabah pada perusahaan.

Hasil penelitian pengaruh hubungan variabel kepuasan terhadap loyalitas nasabah memperoleh koefisien tingkat signifikansi pada probabilitas (p) sebesar 0,000 (kurang dari 0,05) serta koefisien beta standardized sebesar 0,270 yang 
berarti bahwa hasil penelitian ini mendukung $\mathrm{H}_{3}$ dan menunjukan bahwa kepuasan berpengaruh positif dan signifikan terhadap loyalitas nasabah. Hasil tersebut dapat mengindikasikan bahwa perusahaan yang dapat meningkatkan kepuasan nasabah terhadap perusahaan akan berpengaruh pada loyalitas nasabah yang tinggi.

Pengujian hipotesis peran kepuasan dalam memediasi hubungan CRM dengan loyalitas nasabah Bank Mega telah diuji dengan Uji Sobel. Hasil uji memperoleh nilai $\mathrm{z}$ sebesar 2,70 dimana nilai lebih dari 1,96 dan pada tingkat signifikansi probabilitas (p) sebesar 0,000 yang kurang dari 0,05 yang dapat menunjukan bahwa hasil penelitian ini mendukung $\mathrm{H}_{4}$. Hasil tersebut membuktikan bahwa kepuasan nasabah mampu mempengaruhi secara parsial hubungan CRM terhadap loyalitas nasabah. Implikasi penelitian ini adalah CRM merupakan salah satu indikator dalam membangun kepuasan dan berujung pada loyalitas nasabah. Hasil penelitian ini menunjukan bahwa CRM berpengaruh signifikan terhadap kepuasan dan berpengaruh signifikan terhadap loyalitas nasabah Bank Mega. Hasil ini mengindikasikan bahwa perusahaan perlu memperhatikan strategi CRM untuk meningkatkan kepuasan dan berakibat juga pada meningkatnya loyalitas nasabah. Kepuasan nasabah merupakan harapan pelanggan yang dapat dipenuhi oleh perusahaan dan dapat berkelanjutan sehingga mengakibatkan pelanggan loyal terhadap perusahaan. Hasil penelitian ini menunjukan bahwa kepuasan berpengaruh positif signifikan terhadap loyalitas dan kepuasan mampu memediasi hubungan CRM terhadap loyalitas nasabah. Hal ini mengindikasikan bahwa perusahaan perlu menjaga kepuasan nasabah agar 
loyalitas dapat diperoleh perusahaan. Keterbatasan penelitian adalah penelitian ini termasuk penelitian jangka pendek (cross sectional) dan skala penelitian ini kecil.

\section{SIMPULAN DAN SARAN}

CRM berpengaruh positif terhadap loyalitas nasabah. Hal tersebut mengindikasikan bahwa semakin baik perusahaan meningkatkan strategi CRM dalam pelayanan perbankan, maka semakin tinggi pula loyalitas nasabah terhadap perusahaan. CRM berpengaruh positif terhadap kepuasan nasabah. Hal tersebut menunjukan bahwa semakin baik perusahaan menerapkan hubungan jangka panjang melalui CRM, maka semakin tinggi kepuasan nasabah akan diraih. Kepuasan berpengaruh positif terhadap loyalitas nasabah. Hal tersebut mengindikasikan bahwa semakin tinggi tingkatKepuasan nasabah pada perusahaan Bank Mega, maka semakin tinggi pula tingkat loyalitas yang dimiliki nasabah pada perusahaan. Peran kepuasan nasabah signifikan memediasi hubungan CRM dengan loyalitas nasabah.

Saran yang dapat diberikan berdasarkan kesimpulan yang diperoleh bagi pihak yang membutuhkan adalah Bank Mega dalam mempertahankan loyalitas nasabah adalah dengan memberikan kualitas produk yang baik secara berkesinambungan sehingga nasabah senantiasa memberikan informasi baik kepada nasabah maupun calon nasabah lainnya untuk menggunakan produk Bank Mega. Perusahaan Bank Mega dalam mempertahankan CRM nasabah adalah dengan memberikan komitmen dalam pelayanan transaksi perbankan. Bank Mega dalam mempertahankan kepuasan nasabah adalah melalui pemberian jaminan 
produk sehingga nasabah dapat percaya dalam menggunakan produk perbankan perusahaan.

\section{REFERENSI}

Anggabrata Wisnu DM, dan Rahanata, Bayu G. (2015). Pengaruh Kualitas Pelayanan Terhadap Kepuasan Nasabah Pada PT. BPR Balidana Niaga Denpasar. E-Jurnal Manajemen Universitas Udayana, 4(5), 1-10.

Ariyunita Supar, Wina DA dan Suasana, Ketut IGA. (2017). Peran Kepuasan Pelanggan dalam Memediasi Pengaruh Customer Relationship Management terhadap Loyalitas Pelanggan. E-Jurnal Manajemen Universitas Udayana, 6(3), 1-28.

Aswan, Khairil. (2013). Pengaruh Kepuasan Nasabah atas Dimensi Kualitas Pelayanan Terhadap Loyalitas Nasabah Tabungan Sikoci Pada Bank Nagari Cabang Lubuk Sikaping. Jurnal Fakultas Ekonomi Universitas Negeri Padang, 1-15.

Chinomona, R., Mahlangu, D., dan Pooe, D. (2013). Brand service quality, satisfaction, trust and preference as predictors of consumer brand loyalty in the retailing industry. Mediterranean Journal of Social Sciences, 4(14), 181-190.

Eka Putra, Yunanda., Yunus, Muklis., dan Sulaiman. (2017). Pengaruh Customer Relationship Management Terhadap Kepuasan Nasabah Dan Dampaknya Terhadap Loyalitas Nasabah PT. Bank Rakyat Indonesia. Jurnal Manajemen Dan Inovasi, 8(2), 70-83.

Febrianingtyas. (2014). Pengaruh Customer Relationsip Management terhadap Kepuasan dan Loyalitas Nasabah (Survey pada Nasabah Bank Jawa Timur Cabang Gedung Inbis Malang). Jurnal Administrasi Bisnis (JAB). 9.(2), 110.

Rangkuti, Freddy. (2014). Customer Service Satisfaction and Call Center. Jakarta: Gramedia Putraka Utama.

Hartiwi Prabowo, Marcellina. (2013). Pengaruh E-CRM dan Service Quality terhadap Customer Satisfaction dan dampaknya terhadap Customer Loyalty pada PT. XL. Binus Business Review. 4(2), 619-630.

Hastuti, Tuti dan Nasri, Muhammad. (2014). Kualitas Pelayanan, Kepuasan, dan Loyalitas Nasabah: Aplikasi Servqual Model pada Lembaga Keuangan Mikro Syariah Kota Malang. Jurnal Manajemen dan Akuntansi, 3(3), 73-94. 
Hung, S.Y., Chen, C. C., and Huang, N. H. (2014). An integrative approach to understanding customer satisfactionwith e-service of online stores. Journal of Electronic Commerce Research, 15(1), 40-57.

Iriandini, A. P. (2015). Pengaruh Customer Relationship Management terhadap Kepuasan dan Loyalitas Pelanggan. Jurnal Administrasi Bisnis, 23(2), 1-8.

Irianto Marist, Adi., Yuliati Lilik, Noor., dan Najib, Mukhamad. (2014). The Role of Event in Building Brand Satisfaction, Trust and Loyalty of Isotonic Drink. International Journal of Marketing Studies,6(6), 57-65.

Jamali, R., Moshabaki, A., Aramoon, H., and Alimohammadi, A. (2013). Customer relationship management in electronic environment. The Electronic Library, 31(1), 119-130.

Kihara, S. N. (2015). The effect of mobile banking on the competitive advantage of Commercial Banks in Kenya. Unpublished MBA Thesis, United States International University-Africa, 1-48.

Keisidou, Elissave., Sarigiannidis, Lazaros., dan Maditinos, Dimitrios I. (2013). Customer satisfaction, loyalty and financial performance. International Journal of Bank Marketing, 31(4), 259 - 288.

Khedkar, E. B. (2015). Effect Of Customer Relationship Management on Customer Satisfaction andLoyalty. International Journal Of Management (IJM), 6(5), $1-7$.

Kitapci, O., Akdogan, C., dan Dortyol, I. T. (2014). The impact of service quality dimensions on patient satisfaction, repurchase intentions and word-ofmouth communication in the public healthcare industry. Procedia-Social and Beha-vioral Sciences 148, 5(9), 161-169.

Kotler, Phillip \& Amstrong, Gary. (2018), Principles of Marketing, Seventeenth Edition, Pearson Prentice-Hall, New Jersey.

Kotler, Phillip \& Keller, Kevin Lane. (2016), Marketing Management, Fifteenth Edition, Prenctice-Hall, New Jersey.

Kurnia Sari, Yunita. (2017). Pengaruh Kualitas Pelayanan, Relationship Marketing dan Corporate Social Resposibility terhadap Loyalitas dan Kepuasan Nasabah Bank. Jurnal Bisnis \& Manajemen,17(2), 1-14.

Majid Albana. (2013). Aplikasi Regresi Logistik Ordinal untuk Menganalisa Tingkat Kepuasan Pengguna Jasa terhadap Pelayanan di Stasiun Jakarta Kota. Jurnal Universitas Pakuan, 1-76. 
Mang'unyi, Eric E., Khabala, Oumar T., dan Govender, Krishna K.. (2017). The relationship between E-CRM and Customer Loyalty: a Kenyan Commercial Bank case study. Banks and Bank Systems, 12(2), 106-115.

Permadi, Bagus Haryo. (2013). Pengaruh Motif Dan Kepuasan Terhadap Loyalitas Pendengar Program Siaran Obat Tidur Radio EBS FM Surabaya.Jurnal Universitas Airlangga, 9(2), 63-73.

Ramaj, Aurela. (2015). Customer Relationship Management, Customer Satisfaction and Loyalty. Academic Journal of Interdisciplinary Studies MCSER Publishing, Rome-Italy, 4(3), 594-599.

Ramli, A. H., dan Sjahruddin, H. (2015). Building patient loyalty in Healthcare services. International Review of Management and Business Research, 4(2), 301-401.

Rizan, Mohammad, Warokka, Ari, dan Listyawati, Dewi. (2014). Relationship Marketing and Customer Loyalty: Do Customer Satisfaction and Customer Trust Really Serve as Intervening Variables?.Journal of Marketing Research and Case Studies. 2014(2014), 1-12.

Rosy Damayanti, Adila Yeni. (2018). Pengaruh Customer Relationship Management (CRM) terhadap Loyalitas Pelanggan dengan Kepuasan Pelanggan sebagai Variabel Intervening PT. Nasmoco Abadi Motor Karanganyar (Studi pada Pelanggan yang Menggunakan Jasa Bengkel PT. Nasmoco Abadi Motor Karanganyar). Jurnal Administrasi Bisnis Unoversitas Diponegoro. 1-12.

Sabir, R. I., Ghafoor, O., Hafezz, I., Akhtar, N., dan Rehman, A. U. (2014). Factors affecting custo-mers satisfaction restaurant industry in Pakistan. International Review of Management and Busi-ness Research, 3(2), 869876.

Silvia Ermayanti, Kadek, Sri Suprapti, Ni Wayan dan Sukaatmadja, Putu Gde. (2015). Efek Mediasi Kepuasan Pendengar dalam Hubungan Kualitas Layanan dengan Loyalitas Pendengar Radio Cassanova Bali. E-Jurnal Manajemen Universitas Udayana, 4(6), 1-20.

Tarigan, Riswan E., M. Sugiarto, Arnon., dan Widjaja, Andree E. (2017). Pengaruh Faktor-Faktor Customer Relationship Management (CRM) terhadap Kepuasan Pelanggan: Studi Kasus Hypermart. Jurnal Fakultas Teknik - Universitas Muria Kudus, 4(1), 521-540.

Vanitha, DR.K. (2014). Customer Relationship on Customer Satisfaction. IJSRInternational Journal of Scientific Research, 3(4), 1-3. 
Venerian, Simona dan Opreana, Alin. (2014). Analyzing Mediators of the Customer Satisfaction - Loyalty Relation in Internet Retailing. Expert Journal of Marketing, 2(1), 1-14.

Yulianti, Luli, Sjahruddin, Herman, dan Bungatang, Tahir. (2015). Implementasi Customer Relationship Management (CRM) Terhadap Kepuasan dan Loyalitas Pelanggan Pengguna Smartphone Android Merek Samsung. Jurnal Organisasi dan Management, 1(13), 1-15.

Zakaria, Ibhrahim, Ab. Rahman, Baharom, Othman, Abdul Kadir, Mohamed Yunus, Noor Azlina, Dzulkipl, Mohd Redhuan i, dan Faiz Osman, Mohd Akmal. (2014). The Relationship between Loyalty Program, Customer Satisfaction and Customer Loyalty in Retail Industry: A Case Study. International Conference on Innovation, Management and Technology Research, Malaysia, 129, 23-30.

Website :

Badan Pusat Statistik. (2018). Bank dan Kantor Bank, 2010-1017. https://www.bps.go.id/statictable/2015/09/28/1856/bank-dan-kantor-bank2010-2017.html (Diakses pada 21 November 2018)

Detik. (2011) Kena Sanksi BI, Bank Mega Cuma Bisa Buka 5 Cabang di 2011 https://finance.detik.com/moneter/d-1666153/kena-sanksi-bi-bank-megacuma-bisa-buka-5-cabang-di-2011 (Diakses pada 15 Maret 2018).

Otoritas Jasa Keuangan Indonesia. (2018). Statistika Perbankan Indonesia. https://www.ojk.go.id/id/kanal/perbankan/data-dan-statistik/statistik perbankan-indonesia/default.aspx (Diakses pada 13 Juli 2018). 